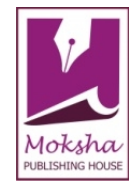

Research Article

www.ijrap.net

\title{
ASSESSMENT OF ANULOMANA KARMA OF HARITHAKI (TERMINALIA CHEBULA RETZ.) AND RECHANA KARMA OF TRIVRIT (OPERCULINA TURPETHUM L.) ON INTESTINAL MOTILITY BY CHARCOAL MEAL TEST
}

\author{
Nidhin PS ${ }^{1}$, Yaligar $\mathrm{MG}^{2} *$, Arun Raj GR ${ }^{3}$, Anusree D ${ }^{4}$ \\ ${ }^{1}$ Research scholar, Department of Samhita and Siddhanta, SDM College of Ayurveda and Hospital, Hassan, Karnataka, \\ India \\ ${ }^{2}$ Associate Professor and Head, Department of Samhita and Siddhanta, SDM College of Ayurveda and Hospital, \\ Hassan, Karnataka, India \\ ${ }^{3}$ Assistant Professor, Department of Kaumarabhritya (Ayurveda Pediatrics), SDM College of Ayurveda and Hospital, \\ Hassan, Karnataka, India \\ ${ }^{4}$ Research Scholar, Department of Panchakarma, Vaidyaratnam PS Varier Ayurveda College of Ayurveda, Kottakal, \\ Kerala, India
}

Received on: 25/05/15 Revised on: 16/04/16 Accepted on: 17/06/16

\author{
*Corresponding author \\ E-mail: dr.nidhinps@gmail.com
}

DOI: $10.7897 / 2277-4343.073108$

\begin{abstract}
The study was conducted to assess the effect of Anulomana Karma of Harithaki and Rechana Karma of Trivrit on fecal output in experimental models. 19 mice were selected, which were separated into 3 groups. Each mouse was kept in separate metabolic cages after proper labeling for identity. Areas were specifically marked for identification of each mice and their respective body weights in three groups A, B and C with 7, 6 and 6 mice respectively. Data showed a decrease in percentage of travel of charcoal in Harithaki group compared to control group and an increase in percentage of travel of charcoal in Trivrit group compared to control group. In Ayurveda, Harithaki (Terminalia chebula Retz.) is considered to be the best drug which could be used almost in all stages of life, having versatile properties and actions; one among them is Anulomana Karma. Anulomana is a Karma in which initially there occurs Paka of Mala which is continued by breaking the bondage and then it is excreted out through Guda. While Rechana Karma is the process in which Malas or Doshas either digested (Pakwa) or undigested (Apakwa) is eliminated through lower gut after converting them to watery form. The best drug of choice for Rechana Karma is Trivrit (Operculina turpethum L.). More time was required for Harithaki to perform Anulomana Karma while reduced time taken by Trivrit to perform Rechana Karma.
\end{abstract}

Keywords: Harithaki, Terminalia chebula Retz., Trivrit, Operculina turpethum L., Anulomana Karma, Rechana Karma, intestinal motility, charcoal meal test

\section{INTRODUCTION}

Experimental pharmacology is a branch of basic medical science which has developed to its present status only during the last few decades. Experimental studies are carried out mainly to find new therapeutic agents or to provide objective parameteric based evidence for the efficacy of non-proven therapeutic agents. Thus the main aim of experimental study is to develop therapeutic agents suitable for human use. They are also employed to assess safety of a preparation by undertaking toxicity study on it. Study on mechanism of action is another area where it is used.

There are lots of references available in Ayurveda literature regarding the testing of drug and food on animals for safety of mankind. ${ }^{1}$ Man is supreme in the universe among all living creatures. Hence he does all procedures for his safety and health. Descriptions regarding the animal experiments are given in classics. While mentioning about Vamana Virechana Vyapat, it is quoted that, the fluid which comes out of the body during vyapat should be mixed with food and given to crows and dogs to eat. If they eat it, then it is to be treated as Jivarakta (live or pure blood), and if it is not eaten by them, it should be treated as bleeding from different parts of the body i.e., polluted blood. ${ }^{2}$ It is also mentioned that any procedure which is expected to be performed on human being should undergo trials on animals or other materials having similar characteristics. ${ }^{3}$

In Ayurveda, Harithaki (Terminalia chebula Retz.) ${ }^{4-6}$ is considered to be the best drug which could be used almost in all stages of life. Even seven varieties of Harithaki have been mentioned in classics showing how the drug could be used in different clinical conditions. So in short Harithaki is having versatile properties and actions; one among them is Anulomana (Aperients a purging medicine; stimulates evacuation of the bowels) Karma. ${ }^{8}$ Anulomana is a Karma in which initially there occurs Paka of Mala which is continued by breaking the bondage and then it is excreted out through Guda. Coming to Rechana Karma (purgative resulting in more fluid evacuation), its a process in which Malas or Doshas either digested (Pakwa) or undigested (Apakwa) is eliminated through lower gut after converting them to watery form. The best drug of choice for Rechana Karma is Trivrit (Operculina turpethum L.). ${ }^{9-10}$

\section{Aims and objectives}

1. To assess Anulomana (Aperients a purging medicine; stimulates evacuation of the bowels) Karma of Harithaki on fecal output in experimental models.

2. To assess Rechana (purgative resulting in more fluid evacuation) Karma of Trivrit on fecal output in experimental models. 


\section{MATERIALS AND METHODS Drugs used}

Group A Control: Charcoal

Group B Test 1: Harithaki

Group C Test 2: Trivrit

\section{Dose and calculations}

The dose of Harithaki for Anulomana and Trivrit for Rechana Karma in human is 12 grams. ${ }^{11-12}$ The dose for experimental study was calculated by extrapolating the human dose to animal dose based on the body surface area ratio by referring Paget's and Barnes (1969) chart. $^{13}$

Mice dose $=$ adult human dose $\mathrm{x}$ body surface area ratio convertible factor

$=12000 \mathrm{mg} \times 0.0026 \times 50$

$=1.56 \mathrm{~g} / \mathrm{kg}$ body weight

$=0.00156 \mathrm{~g} / \mathrm{g}$ body weight

\section{Experimental animals}

Swiss albino mice of either sex were obtained from animal house attached to department of Pharmacology, SDM Centre for Research in Ayurveda and Allied Sciences, Udupi. The experimental protocol was approved by the institutional animal ethics committee under the reference no. SDMCAU/IAEC/2013-14-17. The animals were fed with normal mice diet and water ad libitum throughout the study. They were acclimatized in the laboratory condition for two weeks prior to the experimentation. The housing provided has the following conditions: controlled lighting of $12: 12 \mathrm{~h}$ light and dark cycle, temperature of $25^{\circ} \mathrm{C}$ and relative humidity of approximately $50 \%$.

\section{Animal group}

Healthy mice of either sex were grouped into three different categories. Group I administered with $0.5 \%$ gum acacia along with normal diet and water and served as a normal control. Group II administered with Harithaki 1.56 g / kg body weight, considered as test I and group III administered with Trivrit 1.56 $\mathrm{g} / \mathrm{kg}$ body weight.

Table 1: Marked area for identification of mice and their respective body weights in Group A (Control)

\begin{tabular}{|c|c|}
\hline $\begin{array}{c}\text { Mice (marked area } \\
\text { for identification) }\end{array}$ & $\begin{array}{c}\text { Group A Body } \\
\text { weight (g) }\end{array}$ \\
\hline Head & 30 \\
\hline Neck & 37 \\
\hline Body & 31 \\
\hline Tail & 40 \\
\hline Fore limb & 35 \\
\hline Tip of Tail & 36 \\
\hline No mark & 33 \\
\hline
\end{tabular}

\section{Grouping}

19 mice were selected, which were separated into 3 groups. Each mouse was kept in separate metabolic cages after proper labeling for identity. The marked area for identification in mice and their respective body weights in three groups $\mathrm{A}, \mathrm{B}$ and $\mathrm{C}$ are shown in table 1 to 3 .

\section{Experimental Procedure}

The intestinal motility was determined by administering $0.3 \mathrm{ml}$ of $0.5 \%$ activated charcoal for all groups in specific time interval. 18 minutes after the charcoal administration the mice were sacrificed by cervical dislocation, and the distance travelled by the charcoal in the intestine was measured from the pylorus end of the stomach to end of the caecum. The intestinal motility was calculated by using following formula.

$\%$ travelled $=$ Distance travelled by charcoal meal $\times 100 /$ Total length of small intestine

\section{Analytical Tools}

Statistical package for social science (SPSS) version 20 was used for the data analysis. Separate assessments of each group were carried out using Statistical tools such as Mean, Standard deviation and Standard error of mean. One way Anova followed Dunnet multiple comparison t-test with post hoc test were used for intestinal motility analysis.

\section{OBSERVATIONS AND RESULTS}

Intestinal motility by charcoal meal test in groups $\mathrm{A}, \mathrm{B}$ and $\mathrm{C}$ are detailed in table 4 to 6 . The result of percentage of travel of charcoal in Harithaki group is detailed in table 7. Average percentage of charcoal travelled was 54.75 with 6.32 as standard error of mean. Data shows there was a decrease in percentage of travel of charcoal in Harithaki group compared to control group and the data shows statistically non-significant in Harithaki group. The result of percentage of travel of charcoal in Trivrit group is detailed in table 8 . Average percentage of charcoal travelled was 74.19 with 8.52 as standard error of mean. Data shows there was an increase in percentage of travel of charcoal in Trivrit group compared to control group. But the data shows statistically non-significant in Trivrit group.

Table 2: Marked area for identification of mice and their respective body weights in Group B (Harithaki)

\begin{tabular}{|c|c|}
\hline $\begin{array}{c}\text { Mice (marked area } \\
\text { for identification) }\end{array}$ & $\begin{array}{c}\text { Body weight } \\
\text { (g) }\end{array}$ \\
\hline Head & 38 \\
\hline Neck & 38 \\
\hline Body & 40 \\
\hline Tail & 40 \\
\hline Fore limb & 30 \\
\hline No mark & 37 \\
\hline
\end{tabular}

Table 3: Marked area for identification of mice and their respective body weights in Group C (Trivrit)

\begin{tabular}{|c|c|}
\hline Mice (marked area for identification) & Body weight (g) \\
\hline Head & 40 \\
\hline Neck & 46 \\
\hline Body & 40 \\
\hline Tail & 28 \\
\hline Fore limb & 32 \\
\hline No mark & 30 \\
\hline
\end{tabular}


Table 4: Intestinal motility by charcoal meal test in group A (Control)

\begin{tabular}{|c|c|c|c|c|c|c|c|}
\hline $\begin{array}{c}\text { Mice } \\
\text { Identity }\end{array}$ & $\begin{array}{c}\text { Body } \\
\text { weight } \\
\text { (g) }\end{array}$ & $\begin{array}{l}\text { Dose } \\
(\mathrm{ml})\end{array}$ & $\begin{array}{c}\text { Time of charcoal meal } \\
\text { administration }(\mathrm{am} / \mathrm{pm})\end{array}$ & $\begin{array}{l}\text { Time of sacrifice } \\
\text { (am/pm) }\end{array}$ & $\begin{array}{c}\text { Total length of } \\
\text { intestine } \\
(\mathrm{cm})\end{array}$ & $\begin{array}{c}\text { Distance } \\
\text { travelled by } \\
\text { charcoal }(\mathbf{c m})\end{array}$ & $\begin{array}{c}\% \\
\text { travelled }\end{array}$ \\
\hline Head & 31 & 0.3 & 12.00 & 12.18 & 46.8 & 32.20 & 68.80 \\
\hline Neck & 40 & 0.3 & 12.01 & 12.19 & 42.2 & 23.40 & 55.45 \\
\hline Body & 35 & 0.3 & 12.02 & 12.20 & 44.8 & 29.20 & 65.18 \\
\hline Tail & 36 & 0.3 & 12.03 & 12.21 & 40 & 29.60 & 74.00 \\
\hline Fore limb & 33 & 0.3 & 12.04 & 12.22 & 46.7 & 29.5 & 63.17 \\
\hline Tip of tail & 30 & 0.3 & 12.05 & 12.23 & 42.8 & 24.00 & 57.14 \\
\hline No mark & 37 & 0.3 & 12.06 & 12.24 & 51.8 & 29.10 & 56.17 \\
\hline
\end{tabular}

Table 5: Intestinal motility by charcoal meal test in group B (Harithaki)

\begin{tabular}{|c|c|c|c|c|c|c|c|}
\hline $\begin{array}{c}\text { Mice } \\
\text { Identity }\end{array}$ & $\begin{array}{c}\text { Weight } \\
\mathbf{( g )}\end{array}$ & $\begin{array}{c}\text { Dose } \\
\mathbf{( m )}\end{array}$ & $\begin{array}{c}\text { Time of charcoal } \\
\mathbf{a d m i n i s t r a t i o n} \\
\mathbf{( a m} / \mathbf{p m})\end{array}$ & $\begin{array}{c}\text { Time of } \\
\text { sacrifice } \\
\mathbf{( a m} / \mathbf{p m})\end{array}$ & $\begin{array}{c}\text { Total length of } \\
\text { intestine } \\
(\mathbf{c m})\end{array}$ & $\begin{array}{c}\text { Distance travelled } \\
\text { by charcoal } \\
\text { (cm) }\end{array}$ & $\begin{array}{c}\text { \% } \\
\text { travelled }\end{array}$ \\
\hline Head & 38 & 1.18 & 11.30 & 11.48 & 45.20 & 28.80 & 63.72 \\
\hline Neck & 38 & 1.18 & 11.31 & 11.49 & 55.60 & 35.40 & 63.67 \\
\hline Body & 40 & 1.24 & 11.32 & 11.50 & 54.50 & 32.50 & 65.14 \\
\hline Tail & 40 & 1.24 & 11.33 & 11.51 & 51.80 & 34.40 & 66.40 \\
\hline Fore limb & 30 & 1.54 & 11.34 & 11.52 & 35.30 & 12.20 & 34.56 \\
\hline No Mark & 37 & 10.05 & 11.35 & 11.53 & 48.50 & 17.00 & 35.05 \\
\hline
\end{tabular}

Table 6: Intestinal motility by charcoal meal test in group $\mathrm{C}$ (Trivrit)

\begin{tabular}{|c|c|c|c|c|c|c|c|}
\hline $\begin{array}{c}\text { Mice } \\
\text { identity }\end{array}$ & $\begin{array}{c}\text { Weight } \\
(\mathbf{g})\end{array}$ & $\begin{array}{c}\text { Dose } \\
(\mathbf{m l})\end{array}$ & $\begin{array}{c}\text { Time of charcoal meal } \\
\text { administration } \\
(\mathbf{a m} / \mathbf{p m})\end{array}$ & $\begin{array}{c}\text { Time of } \\
\text { sacrifice } \\
\mathbf{( a m} / \mathbf{p m})\end{array}$ & $\begin{array}{c}\text { Total length } \\
\text { of intestine } \\
(\mathbf{c m})\end{array}$ & $\begin{array}{c}\text { Distance } \\
\text { travelled by } \\
\text { charcoal }\end{array}$ & $\begin{array}{c}\text { \%o } \\
\text { travelled }\end{array}$ \\
\hline Head & 40 & 1.25 & 12.00 & 12.18 & 49.10 & 46.70 & 95.11 \\
\hline Neck & 46 & 1.44 & 12.01 & 12.19 & 47.20 & 40.00 & 84.75 \\
\hline Body & 40 & 1.25 & 12.02 & 12.20 & 48.20 & 19.8 & 41.08 \\
\hline Tail & 28 & .87 & 12.03 & 12.21 & 42.40 & 39.3 & 92.69 \\
\hline Fore limb & 32 & .99 & 12.04 & 12.22 & 49.00 & 29.8 & 60.87 \\
\hline No Mark & 30 & .94 & 12.05 & 12.23 & 46.00 & 32.5 & 70.65 \\
\hline
\end{tabular}

Table 7: Result of percentage of travel of charcoal in Harithaki group

\begin{tabular}{|c|c|c|}
\hline GROUP & $\begin{array}{c}\text { \% travelled } \\
\text { MEAN } \pm \text { SEM }\end{array}$ & \% change \\
\hline Group A (Control) & $62.84 \pm 2.66$ & -- \\
\hline Group B (Test 1) & $54.75 \pm 6.32$ & 12.87 \\
\hline
\end{tabular}

Table 8: Result of percentage of travel of charcoal in Trivrit group

\begin{tabular}{|c|c|c|}
\hline GROUP & $\begin{array}{c}\text { \% travelled } \\
\text { MEAN } \pm \text { SEM }\end{array}$ & \% change \\
\hline Group A (Control) & $62.84 \pm 2.66$ & -- \\
\hline Group C (Test 2) & $74.19 \pm 8.52$ & 18.06 \\
\hline
\end{tabular}

\section{DISCUSSION}

In Harithaki group, average percentage of charcoal travelled was 54.75 with 6.32 as standard error of mean. Data shows there was a decrease in percentage of travel of charcoal in Harithaki group compared to control group and the data shows statistically nonsignificant in Harithaki group. Average percentage of charcoal travelled was $54.75 \pm 6.32$ showed the intestinal motility reducing effect compared to control group. This showed more time was required for Harithaki to perform Anulomana Karma. ${ }^{14}$ In Trivrit group, average percentage of charcoal travelled was 74.19 with 8.52 as standard error of mean. Data shows there was an increase in percentage of travel of charcoal in Trivrit group compared to control group. But the data shows statistically non-significant in Trivrit group. Average percentage of charcoal travelled was $74.19 \pm 8.52$ showing the intestinal motility enhancing effect of Rechana Karma.

\section{CONCLUSION}

Intestinal motility of a drug can be easily found out with the help of charcoal meal test. A result found in a particular group is justifiable only if the obtained data is compared with the control. The results showed that in charcoal meal test, more time was required for Harithaki to perform Anulomana Karma justifying the classical reference of Anulomana Karma. As stated earlier Anulomana Karma acts by converting Apakwa Mala into Pakwa. This can take more time since whole of Mala has to be made Pakwa before expulsion which may be the probable reason for reducing intestinal motility of Harithaki. Intestinal motility effect was enhanced by Rechana Karma in charcoal meal test in Trivrit group justifying the Ayurveda classics. Rechana Karma acts by converting Malas and Doshas into watery form, no matter whether it is Pakwa or Apakwa which may be reason for reduced time taken by Trivrit to perform Rechana Karma. 


\section{ACKNOWLEDGEMENT}

Authors are highly grateful to the constant support of Dr. Mallika KJ, Dean (Academics), SDM College of Ayurveda, Hassan and Dr. Girish KJ, Research co-ordinator, SDM College of Ayurveda, Hassan. The Authors thank Dr. B. Ravishankar, Director, SDM Centre for Research in Ayurveda and Allied Sciences for providing the facilities for their guidance.

\section{REFERENCES}

1. Ranjita Vaghamshi, Mundeep Jaiswal, Patgiri BJ, Prajapati PK, Ravishankar B, Shukla VJ. A comparative pharmacological evaluation of Taila (oil) and Ghrita (ghee) prepared with Guduchi (Tinospora cordifolia). Ayu. 2010 Oct-Dec; 31(4): 504-508.

2. Acharya JT. Charaka Samhita by Agnivesa, Reprint ed. Varanasi: Chaukhamba Orientalia; 2011. p.708.

3. Ethical guidelines for biomedical research on human participants [Internet]. Director-General New Delhi: Indian Council of Medical Research; 2006 Oct [cited 2015 May 12]. Available from: http://icmr.nic.in/ethical_guidelines.pdf.

4. Raj GRA, Shailaja U, Rao PN, Ajayan S. Review on the concept of Immunomodulation in Ayurveda with special emphasis on Prakara yoga. Int J Pharm Sci Res 2014; 5(4): 1116-23.

5. Arun Raj GR, Shailaja U, Rao Prasanna N, Mallanavar V. Review on the therapeutic efficacy of an Ayurvedic compound drug in chronic tonsillitis in children. Unique journal of pharmaceutical and biological sciences 2013; $1(2): 2-11$.

6. Arun Raj GR, Shailaja U, Parikshit Debnath, Subhadip Banerjee, Prasanna N Rao. Exploratory studies on the therapeutic effects of Kumarabharana Rasa in the management of chronic tonsillitis among children at a tertiary care hospital of Karnataka. Journal of Traditional and Complementary Medicine. 2014.1-5.
7. Agnivesha. In: Charaka, Dridhabala, Charaka Samhita, with Ayurveda Dipika commentary of Chakrapanidatta. Reprint Edition. Vaidya Jadavaji Trikamji Acharya., editor. Varanasi: Chaukhamba Surbharati Prakashana; 2009. p. 377. Chikitsasthana, Rasayana Adhyaya, Abhayamalakiya Pada 1/1/30.

8. Jirankalgikar YM, Ashok BK, Dwivedi RR. A comparative evaluation of intestinal transit time of two dosage forms of Haritaki [Terminalia chebula Retz.]. Ayu. 2012 Jul-Sep; 33(3): 447-449.

9. Vidyasagar SP (ed). Sarangadhara Samhita of Sarangadhara, Reprint ed. Varanasi: Chaukhambha Orientalia.2012. p.35.

10. Arun Raj GR, Shailaja U, Rao Prasanna N. Preventive medicine in children: An Ayurvedic Approach Highlighting Native Vaccinations. International Journal of Innovative Research and Development 2013; 2(6):886-893.

11. Vidyasagar SP (ed). Sarangadhara Samhita of Sarangadhara, Reprint ed. Varanasi: Chaukhambha Orientalia.2012. p.174.

12. Acharya JT. Charaka Samhita by Agnivesa, Reprint ed. Varanasi: Chaukhamba Orientalia; 2011. p.95.

13. Paget GE, Barnes JM. Evaluation of drug activities, pharmacometrics, Lawrance DR, Bacharach AL, editors. New York: Academic press; 1964. Vol I. p. 161.

14. Shailaja U, Rao Prasanna N, Arun Raj GR, Mallannavar V. Effect of Kumarabharana rasa on chronic tonsillitis in children: A pilot clinical study. Int. J. Res. Ayurveda Pharm. 2013; 4(2):153-157 DOI: 10.7897/2277-4343.04213

\section{Cite this article as:}

Nidhin PS, Yaligar MG, Arun Raj GR, Anusree D. Assessment of anulomana karma of harithaki (Terminalia chebula Retz.) and rechana karma of Trivrit (Operculina turpethum L.) on intestinal motility by charcoal meal test. Int. J. Res. Ayurveda Pharm. May - Jun 2016;7(3):36-39 http://dx.doi.org/10.7897/22774343.073108

\section{Source of support: Nil, Conflict of interest: None Declared}

Disclaimer: IJRAP is solely owned by Moksha Publishing House - A non-profit publishing house, dedicated to publish quality research, while every effort has been taken to verify the accuracy of the content published in our Journal. IJRAP cannot accept any responsibility or liability for the site content and articles published. The views expressed in articles by our contributing authors are not necessarily those of IJRAP editor or editorial board members. 